\section{Fortettet og bra om behandlingsresistens ved psykiske lidelser}

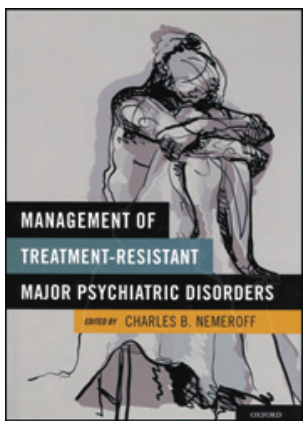

Charles B. Nemeroff, red.

Management of treatment-resistant major psychiatric disorders

366 s, tab, ill. Oxford: Oxford University Press, 2012. Pris GBP 55

ISBN 978-0-973998-1

Boken bør appellere bredt til leger som behandler mennesker med psykiske lidelser, fra allmennleger til spesialister i psykiatri, men også til kliniske forskere.

Det er 15 kapitler, hvorav det første omhandler behandlingsresistens som generelt fenomen. De øvrige kapitlene er viet de ulike terapiområdene depresjon, bipolar lidelse, ulike angstlidelser, anorexia og bulimia nervosa, schizofreni, rusmisbruk, personlighetsforstyrrelser og insomni. I siste kapittel tar forfatterne for seg stemnings- og angstlidelser hos barn og ungdom.

De fleste kapitlene inneholder tabeller, men figurene er få. Kapitlene har en stringent oppbygning og avsluttes med en oppsummering/konklusjon og eventuelle interessekonflikter, i tillegg til fyldige referanselister.

Bidragsyterne tar for seg det svært utbredte problemet behandlingsresistens ved psykiske lidelser. Begrepet er ikke entydig definert, men avklares i forhold til de ulike lidelsene innledningsvis i kapitlene. Kapitlene er skrevet av eksperter med omfattende publikasjonslister innenfor sine respektive områder. De tar i all hovedsak for seg medikamentell og psykoterapeutisk behandling, selv om også annen biologisk behandling som elektrokonvulsiv terapi og transkraniell stimulering omtales i relevante kapitler. Evidensgrunnlaget for både førstevalgsbehandling og strategier ved behandlingsresistens presenteres på en nøktern måte med påfølgende råd om mulige fremgangsmåter når førstelinjetiltakene ikke fører til målet. På samme måte påpeker forfatterne også de mange hullene i evidensgrunnlaget, og i noen grad fremmer de anbefalinger for videre kliniske studier.

Et karakteristisk trekk er bokens knappe form. Selv om det er forskjeller mellom kapitlene, er teksten gjennomgående stramt redigert og rikt understøttet av oppdaterte referanser. Fordelen er at leseren i løpet av de om lag 350 sidene får svært mye oppdatert og klinisk relevant kunnskap om et komplisert tema. Boken blir på grunn av det begrensede omfanget overkommelig lesning fra perm til perm, og fungerer ikke bare som et oppslagsverk. Hensynet til knapphet har selvsagt også sin pris: Teksten er tett og krevende, selv om tabellene bidrar til løse opp teksten noe. Videre har man på redaksjonelt nivå formodentlig måttet velge noe vekk. For eksempel tar man i kapitlet om behandlingsresistente personlighetsforstyrrelser bare for seg den emosjonelt ustabile personlighetsforstyrrelsen. Videre begrenser man seg til å omtale biologisk og psykoterapeutisk behandling, mens man for eksempel ikke nevner psykososiale tiltak. Til sist, som redaktøren selv er inne på, er kapitlene, med ett unntak, skrevet av amerikanske forfattere og refererer til et amerikansk psykofarmakologisk armamentarium. Sistnevnte oppleves ikke av undertegnede som noe vesentlig problem.

Jeg anbefaler boken på det varmeste til hjelp i behandlingsresistente situasjoner hvor man ellers har lite oppdatert og systematisert litteratur å hjelpe seg med.

\section{Aktiv læring på sykehuset}

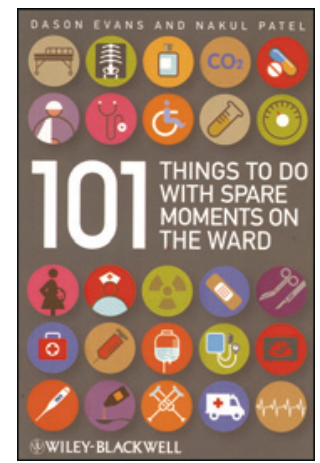

Dason Evans, Nakul Patel

101 things to do with spare moments on the ward

147 s, ill. Chichester: Wiley-Blackwell, 2012.

Pris GBP 15

ISBN 978-1-4051-5985-2

Dette er en liten idébok for medisinstudenter, leger i utdanning og andre som vil lære. Boken inneholder råd om hva vi kan gjøre under kliniske opphold for å lære best mulig. Forfatterne har to mål: Det første er å gi konkrete tips om gode læringssituasjoner under kliniske utplasseringer. Det andre er å oppmuntre oss til å finne enda flere læringsarenaer i hverdagen og å fortelle andre om dem.

Tipsene er sortert inn i flere kapitler, som klinisk kommunikasjon, praktiske prosedyrer og nysgjerrighet. Aktiv læring gir dyp læring, skriver forfatterne, og forslagene er nesten uten unntak situasjoner der studenten selv lærer gjennom å være aktiv.

Noen råd er tradisjonelle: Sitt i en gruppe på to-tre studenter, og vurder alle dagens røntgenbilder før røntgenmøtet. Vær mye hos pasientene også utenom obligatorisk undervisning. Andre råd føles ganske moderne: Se symptomfilmer på YouTube. Bruk Googlebilder, og la bildene på førsteoppslaget være din visuelle knagg når du skal lære om en ny diagnose.

Det finnes mange råd om hvordan noen få minutters ventetid kan brukes: Otoskoper rutinemessig hver gang du venter på lektoren i allmennpraksis. Lag quiz fra en tilfeldig side i Felleskatalogen hvis du må vente på at previsitten starter. Konkurransen om å finne flest feil i sengepostens medisinlister er også tatt med.

Tipsene kommer stort sett fra britiske medisinstudenter og er sortert og kommentert av to undervisere. I sine beste partier har boken noe av den samme underfundige visdommen som Oxford Handbook of Clinical Medicine, men ofte føles den litt uredigert. Det samme sies flere ganger, og mye er skrevet $i$ et muntlig språk. Tipsene er attpåtil trykt med en håndskriftliknende font, som dessverre gjør teksten litt rotete og tunglest.

Jeg synes dette veies opp av mange treffende triks, som under punkt 69: «Observer hvem av de unge legene som har best samarbeid med sykepleierne. Hvordan får de det til? Sammenlikn deres oppførsel og holdninger med holdningene til dem som finner sykepleierne utfordrende.»

Boken er liten nok til å passe i en frakkelomme, men jeg synes den passer bedre på pauserommet. Jeg vil også anbefale at den ligger på nattbordet hos lektoren som vil få i gang mer aktiv læring i neste ukes undervisningsøkter.

Martin Aasbrenn

Sykehus Innlandet

Tynset 